$\begin{array}{llcccccrr}\text { Volume } & 12, \quad \text { Nomor } & 1, \quad \text { Mei } & \text { 2020, } & \text { pp } & 58-72 & \text { Copyright } & \text { C } & 2017 \\ \text { Jurnal } & \text { Akuntansi, } & \text { Program } & \text { Studi } & \text { Akuntansi, } & \text { Fakultas } & \text { Ekonomi, } \\ \text { Universitas } & \text { Kristen } & \text { Maranatha. } & \text { ISSN } & 2085-8698 & \text { e-ISSN } & 2598-4977 .\end{array}$

http://journal.maranatha.edu

\title{
Pengaruh Sistem Desentralisasi dan Ketidakpastian Lingkungan terhadap Kinerja Manajerial yang Dimoderasi oleh Asimetri Informasi
}

\author{
Merna \\ Fakultas Ilmu Sosial dan Humaniora Program Studi Akuntansi-Universitas Bunda Mulia \\ (Lodan Raya No 2, Jakarta Utara) \\ mernasurjadi@gmail.com
}

\begin{abstract}
The purpose of this study was to examine and analyze the influence of decentralization systems and environmental uncertainty on managerial performance. This study also examine and analyze the role of information asymmetry as a moderating variable in the relationship between the effect of decentralization systems and environmental uncertainty on managerial performance. The population of this study is the banking industry in the city of Jakarta. The sample of this research is employees with upper level heads in private banking companies listed on the Indonesia Stock Exchange. This study uses quantitative methods using the type of research carried out with quantitative data. Data is collected by sending questionnaires. The questionnaires sent were 150 questionnaires and the number returned and could be used in this study as many as 109 questionnaires. The results of this study indicate that: (i) The decentralized system has a positive effect on the company's managerial performance; (ii) Environmental uncertainty has a positive effect on company managerial performance; (iii) Information asymmetry strengthens the relationship between decentralized systems and company managerial performance; and (iv) Information asymmetry weakens the relationship between environmental uncertainty and company managerial performance. Suggestions for future research, that can use research population from other sector industries in the Indonesia Stock Exchange in addition to the banking sector. This research has a contribution to company management to pay attention to managerial performance so that the company gets better results.
\end{abstract}

Keywords: Decentralization System, Environmental Uncertainty, Managerial Performance, Information Asymmetry

\begin{abstract}
Abstrak
Penelitian ini bertujuan untuk menguji dan menganalisa pengaruh sistem desentralisasi dan ketidakpastian lingkungan terhadap kinerja manajerial.Penelitian ini juga menguji dan menganalisa peran asimetri informasi sebagai variabel pemoderasi hubungan antara 58
\end{abstract}


pengaruh sistem desentralisasi dan ketidakpastian lingkungan terhadap kinerja manajerial. Populasi penelitian ini adalah industri perbankan di kota Jakarta. Sampel penelitian ini adalah karyawan dengan jenjang kepala bagian keatas pada perusahaan perbankan swasta yang terdaftar di Bursa Efek Indonesia.Penelitian ini menggunakan metode kuantitatif dengan menggunakan jenis penelitian yang dilakukan dengan pendekatan dan data bersifat kuantitatif. Data dikumpulkan dengan cara mengirimkan kuesioner. Kuesioner yang dikirimkan sebanyak 150 kuesioner dan jumlah yang dikembalikan dan dapat digunakan di dalam penelitian ini sebanyak 109 kuesioner. Hasil penelitian ini menunjukkan bahwa: (i) Sistem desentralisasi berpengaruh positif terhadap kinerja manajerial perusahaan; (ii) Ketidakpastian lingkungan berpengaruh positif terhadap kinerja manajerial perusahaan; (iii) Asimetri informasi memperkuat hubungan antara sistem desentralisasi terhadap kinerja perusahaan; dan (iv) Asimetri informasi memperlemah hubungan antara ketidakpastian lingkungan terhadap kinerja manajerial perusahaan. Saran untuk penelitian yang mendatang, bahwa bisa menggunakan populasi penelitian dari indutri sektor lainnya yang ada di Bursa Efek Indonesia selain sektor perbankan.Penelitian ini memliki kontribusi bagi manajemen perusahaan untuk memperhatikan kinerja manajerialnya agar perusahaan mendapatkan hasil yang lebih baik.

\section{Kata Kunci: Sistem Desentralisasi, Ketidakpastian Lingkungan, Kinerja Manajerial, Asimetri Informasi}

\section{Pendahuluan}

\section{Latar Belakang}

Memasuki Masyarakat Ekonomi ASEAN (MEA), era perdagangan bebas untuk barang, jasa, investasi, tenaga kerja terampil, dan aliran modal yang lebih bebas akan terjadi (www.asean.org). Keadaan ini membuat perusahaan akan menghadapi persaingan yang semakin kompetitif disertai adanya perubahan lingkungan bisnis secara cepat dan mendadak. Oleh karena itu, agar dapat bertahan dan berkembang perusahaan harus mampu melakukan penyesuaian yang kreatif terhadap kondisi yang harus dihadapinya, dengan melakukan perubahan strategi dan pengendalian manajemen yang lebih baik.Hal ini dimungkinkan bila perusahaan mampu menciptakan kinerja perusahaan yang unggul berupa suatu kinerja manajerial yang berkualitas tinggi.Kinerja manajerial merupakan salah satu faktor yang dapat meningkatkan keefektifan sebuah organisasi atau entitas (Susanto dan Sudono, 2007; dalam Fiolita,
2015).Kinerja manajerial yang berkualitas akan terbentuk bila perusahaan memiliki informasi yang dapat diandalkan. Dengan adanya informasi yang andal akan meningkatkan kemampuan manajer untuk memahami keadaan lingkungan yang sebenarnya dan berfungsi pula dalam mengidentifikasi aktivitas yang relevan (Putri, et al., 2014). Informasi yang dapat diandalkan juga akan mampu mendukung adanya desentralisasi yang dapat meningkatkan strategi bisnis, disamping itu adanya pemanfaatan sistem informasi akuntansi manajemen juga dapat membantu perusahaan menciptakan kinerja perusahaan yang berkualitas dan kompetitif (Fitriani, 2013). Adanya kebutuhan yang tinggi dan mendesak akan informasi yang andal harus disertai dengan kecermatan dalam menyeleksi dan mengolah informasi yang diperoleh. Sehingga informasi tersebut janganlah informasi yang asimetri, karena dapat menyebabkan salah persepsi oleh pihak staf yang menjalankan tugas dan tanggung jawabnya (Mabrurah,2017). 


\begin{abstract}
Desentralisasi merupakan pendelegasian wewenang dan tanggung jawab kepada para manajer.Tingkat pendelegasian itu sendiri menunjukkan sampai seberapa jauh manajemen yang lebih tinggi mengizinkan manajemen yang lebih rendah untuk membuat kebijakan secara independen (Herdiansyah, 2012). Desentralisasi dalam pengambilan keputusan ditujukan untuk meningkatkan kinerja manajer dengan cara mendorong manajer untuk mengembangkan
\end{abstract} kompetensinya. Dengan desentralisasi manajer juga membutuhkan informasi yang lebih luas dan dapat diandalkan karena kesesuaian informasi dengan kebutuhan pembuatan keputusan akan mendukung kualitas keputusan yang diambil, yang pada akhirnya dapat meningkatkan kinerja manajerial. Oleh karena itu informasi yang diterima oleh manajemen perlu dipilih dan dikelompokkan menurut karakteristiknya sehingga informasi tersebut dapat memberikan kontribusi dalam pencapaian kinerja manajerial (Yuliansyah and Khan, 2017; Yuliansyah et al., 2016).

Pencapaian kinerja manajerial yang berkualitas dalam era globalisasi ini bukanlah hal yang mudah.Karena berhadapan dengan kendala berupa perubahan lingkungan bisnis yang pesat yang memicu peningkatan kondisi ketidakpastian lingkungan.Ketidakpastian lingkungan merupakan suatu kondisi lingkungan eksternal yang dapat memengaruhi operasionalisasi perusahaan (Sulistiyowati, 2013). Ketidakpastian lingkungan yang tinggi akan menyebabkan manajer sulit menyusun perencanaan dan pengendalian organisasi yang akurat. Perencanaan yang disusun dalam situasi ketidakpastian lingkungan yang tinggi akan menjadi masalah karena adanya ketidakmampuan manajer untuk memprediksi kondisi pada masa mendatang (Wirjono, 2003).

Berdasarkan latar belakang tersebut peneliti tertarik untuk menguji dan menganalisis pengaruh sistem desentralisasi dan ketidakpastian lingkungan terhadap kinerja manajerial.Penelitian ini juga menguji dan menganalisis peran asimetri informasi sebagai variabel pemoderasi hubungan antara pengaruh sistem desentralisasi dan ketidakpastian lingkungan terhadap kinerja manajerial. Populasi penelitian ini adalah industri perbankan di kota Jakarta. Sampel penelitian ini adalah karyawan dengan jenjang kepala bagian keatas pada perusahaan perbankan swasta yang terdaftar di Bursa Efek Indonesia.

\section{Tujuan Penelitian}

Penelitian ini bertujuan membantu manajemen perusahaan mengetahui bagaimana kinerja manajerial dapat dipengaruhi oleh beberapa hal, diantaranya sistem desentralisasi, ketidakpastian lingkungan, dan asimetri informasi. Selain itu untuk membantu pemangku kepentingan yang ada di perusahaan agar dapat meningkatkan program good corporate governance.Karena sistem desentralisasi dan kondisi ketidakpastian lingkungan ini memerlukan pengawasan yang berkelanjutan sepanjang perusahaan tersebut masih menjalankan kegiatan operationalnya. Penelitian ini juga akan membantu para manajer perusahaan untuk dapat membuktikan adanya peran informasi akuntansi manajemen dalam memengaruhi strategi manajerial untuk menyikapi ketidakpastian lingkungan dan memaksimalkan daya guna dari sistem desentralisasi.

\section{Kerangka Teoritis dan Hipotesis}

\section{Grand Theory}

Agency Theory

Teori keagenan (agency theory) yang membahas tentang adanya hubungan keagenan antara prinsipal dan agen.Hubungan keagenan tercermin antara pihak manajemen (agen) dengan investor (prinsipal).Teori keagenan adalah sebuah 
kontrak antara manajemen (agen) dengan pemilik (prinsipal). Agar hubungan kontraktual ini dapat berjalan lancar, pemilik akan mendelegasikan otoritas pembuatan keputusan kepada manajer. Perencanaan kontrak yang tepat bertujuan untuk menyelaraskan kepentingan manajer dan pemilik dalam hal adanya konflik kepentingan, hal ini merupakan inti dari teori keagenan.

Perspektif teori agensi merupakan dasar yang digunakan untuk memahami isu corporate governance dan earning management.Agensi teori menunjukkan bahwa adanya hubungan yang asimetri antara pemilik dan pengelola, dan untuk menghindari terjadinya hubungan yang asimetri tersebut dibutuhkan suatu konsep yaitu konsep Good Corporate Governance yang bertujuan untuk menjadikan perusahaan lebih sehat.Penerapan corporate governance berdasarkan pada teori agensi, yaitu menjelaskan hubungan antara manajemen dengan pemilik. Manajemen sebagai agen secara moral bertanggung jawab untuk mengoptimalkan keuntungan para pemilik (prinsipal) dan sebagai imbalannya akan memperoleh kompensasi yang sesuai dengan kontrak.

\section{Stakeholder Theory}

Stakeholder atau pemangku kepentingan adalah semua pihak baik internal maupun eksternal perusahaan yang memiliki hubungan baik yang bersifat memengaruhi langsung maupun tidak langsung terhadap perusahaan (Gunawan, 2015).Perusahaan memiliki tanggung jawab kepada setiap kelompok atau individu yang dapat atau telah terpengaruh oleh kewajiban yang dimilikinya terhadap perusahaan.Karena itu perlu dibangun hubungan stakeholder yang sinergis yang mendukung kemajuan perusahaan (Harffman, 2007).Teori stakeholder dapat dibagi menjadi dua cabang yaitu normatif (etika) dan manajerial.

Menurut Deegan dan Unerman (2006), perspektif normatif teori stakeholder memiliki konsep untuk memberikan perlakuan yang sama bagi semua pemangku kepentingan dengan tidak memperhitungkan kekuatan rekening yang dimiliki oleh setiap pemangku kepentingan. Selain itu, menurut Hasan (1998) yang dikutip dalam Deegan dan Unerman (2011), konsep ini akan meminta manajer untuk bekerja agar mampu memberikan manfaat bagi semua pemangku kepentingan. Untuk perspektif manajerial dari teori stakeholder adalah konsep yang memperlakukan pemangku kepentingan dengan memperhatikan kekuatan masing-masing pemangku kepentingan (Ali dan Rizwan, 2013) dan kekuasaannya tergantung pada sumber daya penting yang dimiliki oleh para pemangku kepentingan.

\section{Konsep Teori}

\section{Kinerja Manajerial}

Mulyadi (2006) menyatakan kinerja adalah gambaran mengenai tingkat pencapaian pada pelaksanaan suatu kegiatan atau program atau kebijakan dalam mewujudkan sasaran, tujuan, atau melakukan misi, agar mencapai visi organisasi.Kinerja atau nilai aktivitas kerja dapat diartikan sebagai prestasi yang dapat dicapai perusahaan dalam suatu periode tertentu dalam melaksanakan berbagai program guna mewujudkan sasaran, tujuan, visi, dan misi perusahaan yang tertuang dalam rencana strategis perusahaan tersebut.

Kinerja manajerial merupakan salah satu faktor yang dapat meningkatkan keefektifan sebuah organisasi atau entitas.Kinerja manajerial yang berkualitas sangat dibutuhkan dalam situasi dan lingkungan yang berubah-ubah (dinamis) agar perubahan tersebut dapat direspon secara cepat sehingga keputusan yang diambil serta tindakan organisasi selaras dengan tujuan yang telah ditetapkan.Menurut Mahonay et.al, (1963) dalam Ahmad (2008) dalam Fitriani (2013), kinerja manajerial itu sendiri terdiri dari delapan dimensi kegiatan, yaitu 
perencanaan, investigasi, evaluasi, koordinasi, supervise, pengaturan staf, negosiasi, dan perwakilan.

\section{Sistem Desentralisasi}

Desentralisasi adalah pendelegasian wewenang kepada manajer yang lebih rendah. Delegasi adalah proses penyerahan wewenang dari satu tingkatan manajemen kepada tingkat manajemen berikutnya yang berada dibawahnya (James, 2015). Sedangkan desentralisasi (decentralization) adalah praktek pendelegasian wewenang dan pengambilan keputusan kepada jenjang yang lebih rendah (Hansen and Mowen, 2016).

Jadi desentralisasi merupakan kecenderungan untuk mendelegasikan wewenang yang semakin besar kepada para pejabat dengan tingkat yang lebih rendah serta bidang operasi yang terletak pada lokasi - lokasi yang jauh.Wewenang yang didelegasikan kepada manajer dengan tingkat yang lebih rendah beraneka ragam.Pada titik terendah hanya keputusan beban yang didelegasikan.Pada titik tertinggi, wewenang yang didelegasikan sangat luas yang meliputi keputusan beban, pendapatan, laba dan investasi (Sodikin, 2015).

\section{Ketidakpastian Lingkungan}

Ketidakpastian lingkungan merupakan ketidakmampuan seseorang untuk memprediksi sesuatu secara akurat (Sulistiyowati, 2013). Seseorang berada dalam kondisi ketidakpastian bila ia merasa dirinya tidak memiliki informasi yang cukup untuk membuat prediksi secara akurat, atau bila ia merasa bahwa dirinya tidak mampu membedakan antara data yang relevan dengan data yang tidak relevan. Ketidakpastian lingkungan menurut Rahmiyati (2014) adalah situasi dimana para manajer tidak mempunyai informasi yang cukup mengenai faktor-faktor lingkungan untuk memahami dan meramalkan kebutuhan serta perubahan lingkungan.

\begin{abstract}
Ketidakpastian lingkungan memengaruhi praktik akuntansi manajerial.Karena pada dasarnya ketidakpastian lingkungan merupakan kondisi eksternal yang dapat memengaruhi operasional perusahaan.Hal ini mendorong manajemen perusahaan melakukan penyesuaian terhadap kondisi yang ada dengan melakukan berbagai perubahan dan pengendalian manajemen yang lebih baik. Tercapainya pengendalian manajemen yang lebih baik akan mendorong peningkatan kinerja organisasi (Fiolita, 2015).
\end{abstract}

\section{Asimetri Informasi}

Asimetri informasi merupakan suatu keadaan dimana manajer memiliki akses informasi atas prospek perusahaan yang tidak dimiliki oleh pihak luar perusahaan.Asimetri informasi terjadi karena manajer lebih superior dalam menguasai informasi dibandingkan pihak lain (pemilik atau pemegang saham). Dengan asumsi bahwa individu-individu bertindak untuk memaksimalkan kepentingan diri sendiri, maka dengan informasi asimetri yang dimilikinya akan mendorong manajemen (agent) untuk menyembunyikan beberapa informasi yang tidak diketahui pemilik (principal.) Sehingga dengan adanya asimetri informasi antara manajemen (agent) dengan pemilik (principal) memberikan kesempatan kepada manajer untuk melakukan praktek manajemen laba (earnings management) dalam rangka meningkatkan kinerjanya agar terlihat baik oleh pemilik.

\section{Pengembangan Hipotesis}

\section{Desain Penelitian}

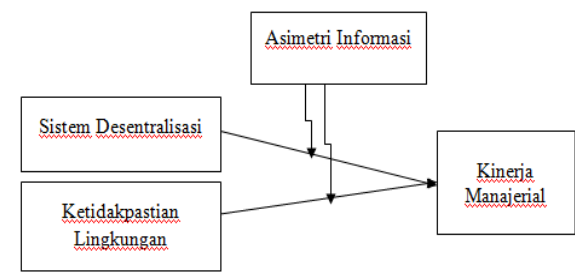


Berdasarkan paparan di atas, hipotesis yang akan diuji dalam penelitian ini adalah:

$\mathrm{H}_{1}$ : Sistem Desentralisasi mempunyai pengaruh secara signifikan terhadap Kinerja Manajerial.

$\mathrm{H}_{2}$ : Ketidakpastian Lingkungan mempunyai pengaruh secara signifikan terhadap Kinerja Manajerial.

$\mathrm{H}_{3}$ : Asimetri Informasi memperkuat pengaruh signifikan antara Sistem Desentralisasi terhadap Kinerja Manajerial.

$\mathrm{H}_{4}$ : Asimetri Informasi memperkuat pengaruh signifikan antara Ketidakpastian Lingkungan terhadap Kinerja Manajerial.

\section{Definisi Operasionalisasi Variabel dan Pengukuran Variabel}

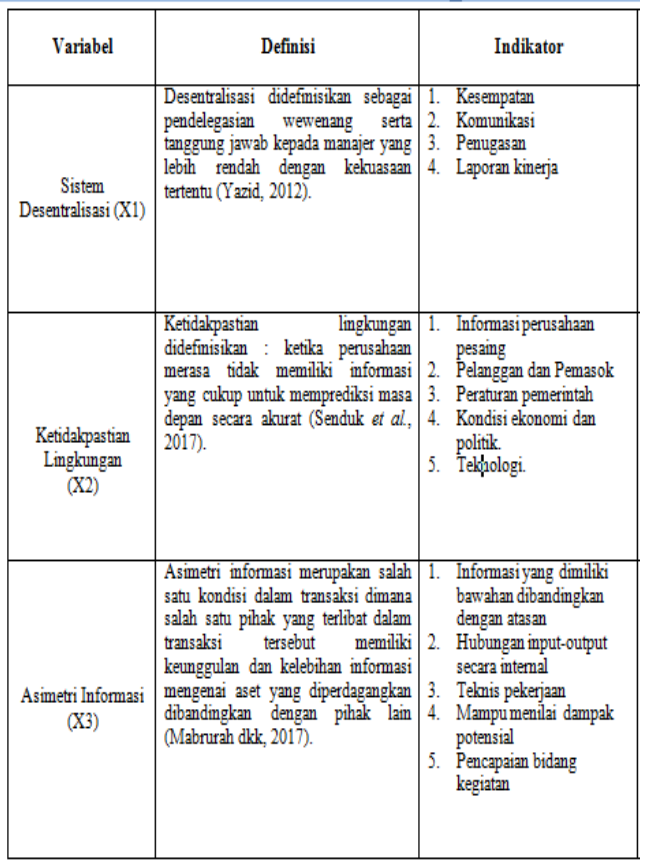

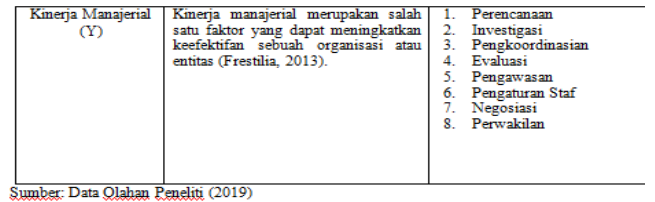

\section{Metode Penelitian}

\section{Prosedur Penelitian}

Dalam penelitian ini, subjek penelitian yang digunakan adalah karyawan dengan jenjang kepala bagian pada perusahaan perbankan swasta yang terdaftar di Bursa Efek Indonesia. Sedangkan, objek penelitian yang akan diteliti adalah sistem desentralisasi, ketidakpastian lingkungan, asimetri informasi, dan kinerja manajerial perusahaan. Penelitian ini menggunakan metode kuantitatif, yaitu penelitian yang dilakukan dengan menggunakan data yang bersifat kuantitatif.Sedangkan jenis penelitian yang digunakan dalam penelitian ini adalah penelitian kausal komparatif yang termasuk dalam bagian asosiatif atau hubungan.Penelitian Asosiatif merupakan penelitian yang bertujuan untuk mengetahui hubungan antara dua variabel atau lebih serta mengetahui pengaruhnya (Sujarweni, 2014:11) dalam Senduk (2017).

\section{Deskripsi Responden}

Penelitian ini dilakukan dengan menyebarkan kuesioner kepada perusahaan perbankan swasta yang terdaftar di Bursa Efek Indonesia (Indonesia Stock Exchange), dimana pembatasan responden yang mengisi kuesioner adalah dengan level jabatan supervisor (kepala bagian) di perusahaan perbankan yang berkedudukan di kota Jakarta. Penelitian ini menggunakan sampel yang terdiri dari 109 Wajib Pajak Orang Pribadi sebagai responden dan dari 150 kuesioner yang disebarkan pada bankbank swasta yang terdaftar di Bursa Efek Indonesia (BEI) yang ada di kota Jakarta, seperti Bank Central Asia (BCA), Bank CIMB Niaga, dan Bank Permata. Dengan responden yang digunakan pada penelitian ini, diharapkan dapat mewakili populasi untuk mengetahui kinerja manajerial pada sub sektor industri perbankan khususnya bank swasta di Indonesia. 


\section{Teknik Analisis Data}

\section{Uji Asumsi Klasik Uji Normalitas}

Ghozali (2013) menyatakan uji normalitas bertujuan menentukan apakah dalam model regresi berdistribusi normal atau tidak berdistribusi normal.Data residual yang berdistribusi normal adalah data yang sebaran nilai datanya memiliki nilai yang memusat di nilai rata-ratanya yang dalam hal ini frekuensi keluar nilai data yang terbanyak terdapat pada nilai rata-rata. Normalitas data residual dapat diuji dengan pengujian one sample kolmogorov smirnov test dengan tingkat $\alpha=5 \%$.

Penentuan uji normalitas didasarkan dari nilai asymp.sig yang diperoleh.Jika nilai asymp.sig. (2-tailed) di atas atau sama dengan 0,05, maka model regresi berdistribusi normal. Namun apabila nilai asymp.sig. (2-tailed) adalah di bawah 0,05, maka model regresi tidak berdistribusi normal. Model regresi yang baik adalah model regresi yang berdistribusi normal.

\section{Uji Multikolinearitas}

Menurut Ghozali (2013), uji multikolinearitas bertujuan untuk menguji apakah di dalam suatu model regresi terjadi korelasi antar variabel independen. Multikolinearitas dapat ditentukan berdasarkan nilai tolerance dan Variance Inflaction Factor (VIF). Apabila nilai tolerance di atas 0,1 dan Variance Inflaction Factor (VIF) di bawah 10, maka dapat disimpulkan tidak terdapat multikolinearitas antar variabel independen.

Namun apabila nilai tolerance di bawah 0,1 dan Variance Inflaction Factor (VIF) di atas 10, maka dikatakan terdapat multikolinearitas antar variabel independen. Model regresi yang baik seharusnya tidak terjadi korelasi di antara variabel independennya yang berarti tidak terdapat multikolinearitas.

\section{Uji Heteroskedastisitas}

Menurut Ghozali (2013), uji heteroskedastisitas dilakukan untuk menguji apakah dalam model regresi terjadi ketidaksamaan variance dari data residual satu pengamatan dengan pengamatan lainnya. Dalam menentukan ada atau tidaknya heteroskedastisitas pada data residual, dapat dilakukan dengan uji glejser pada tingkat $\alpha=5 \%$. Jika nilai sig. (2tailed) di atas atau sama dengan 0,05, maka tidak terdapat heteroskedastisitas.

Namun apabila nilai sig. (2-tailed) adalah di bawah 0,05, maka terdapat heteroskedastisitas. Model regresi yang baik adalah model regresi yang memiliki variance yang sama antara satu pengamatan dengan pengamatan lain yang berarti tidak terdapat heteroskedastisitas.

\section{Uji Autokorelasi}

Ghozali (2013) menyatakan uji autokorelasi bertujuan untuk menguji apakah dalam model regresi linear terdapat korelasi antara kesalahan pengganggu pada periode $t$ dengan kesalahan pengganggu pada periode $\mathrm{t}-1$. Dalam menentukan ada atau tidaknya autokorelasi dapat menggunakan uji Breusch-Godfrey dengan tingkat $\alpha=5 \%$. Jika nilai sig. (2-tailed) di atas atau sama dengan 0,05 , maka tidak terdapat autokorelasi. Namun apabila nilai sig. (2tailed) di bawah 0,05, maka terdapat autokorelasi. Model regresi yang baik adalah model regresi yang tidak terdapat korelasi antar variabel independen terhadap nilai absolut residual yang berarti tidak terdapat autokorelasi.

\section{Uji Hipotesis}

Ghozali (2013) menyatakan regresi berganda (multiple regression) merupakan metode statistik yang digunakan apabila terdapat ketergantungan variabel dependen terhadap satu atau lebih variabel independen. Model regresi berganda yang digunakan untuk menguji hipotesis dalam penelitian ini dijabarkan dalam model persamaan regresi sebagai berikut: 
$\mathrm{Y}=\alpha+\beta 1 \mathrm{X} 1+\beta 2 \mathrm{X} 2+\beta 3 \mathrm{X} 1 * \mathrm{X3}+\beta 4$ $\mathrm{X} 2 * \mathrm{X} 3+\mathrm{e}$

Keterangan:

$\mathrm{Y}=$ Kinerja Manajerial

$\mathrm{X} 1=$ Sistem Desentralisasi

$\mathrm{X} 2=$ Ketidakpastian Lingkungan

$\mathrm{X} 3=$ Asimetri Informasi

$\boldsymbol{\alpha}=$ Konstanta

$\beta 1 \ldots \beta 2=$ Koefisien Regresi

$\mathrm{e}=$ Error

\section{Uji Korelasi dan Koefisien Determinasi}

Menurut (Ghozali, 2011), "Koefisien determinasi $\left(\mathrm{R}^{2}\right)$ mengukur kekuatan hubungan antara dua variabel atau lebih dengan menunjukkan seberapa jauh kemampuan model dalam menerangkan variasi variabel dependen.Nilai koefisien determinasi adalah antara nol dan satu.

Nilai $R^{2}$ yang kecil berarti kemampuan variabel-variabel independen dalam menjelaskan variasi variabel dependen amat terbatas.Nilai yang mendekati satu berarti variabel-variabel independen memberikan hampir semua informasi yang dibutuhkan untuk memprediksi variasi variabel dependen.

\section{Uji Parsial (Uji t)}

Menurut (Priyatno, 2014), uji t bertujuan untuk mengetahui apakah secara parsial (masing-masing) variabel bebas berpengaruh secara signifikan atau tidak terhadap variabel terikat.Hasil uji ini pada SPSS dapat dilihat pada tabel coefficients. Kriteria pengujian dalam uji t adalah :

Jika Sig $<0,05=$ Ho ditolak, artinya signifikan.

Jika Sig $>0,05=$ Ho diterima, artinya tidak signifikan.

\section{Uji Signifikansi Model}

Menurut (Priyatno 2014), tujuan dari uji F adalah untuk menguji signifikansi pengaruh semua variabel bebas terhadap variabel terikat secara bersama-sama
(simultan).Hasil uji ini dalam SPSS dapat dilihat pada tabel ANOVA.

Kriteria pengujian dalam uji $\mathrm{F}$ adalah:

Jika Sig $<0,05=$ Ho ditolak, artinya signifikan.

Jika Sig > 0,05 = Ho diterima, artinya tidak signifikan.

\section{Hasil Penelitian dan Pembahasan}

\section{Hasil Penelitian \\ Deskripsi Responden}

Penyebaran serta pengembalian kuesioner dilaksanakan pada tanggal 01 Februari 2019 sampai dengan 15 Mei 2019.

Tabel 1

Statistika Kuesioner

\begin{tabular}{|l|c|c|}
\hline Keterangan & Jumlah & Persentase \\
\hline $\begin{array}{l}\text { Total } \\
\text { Kuesioner } \\
\text { yang } \\
\text { disebarkan }\end{array}$ & 150 & $100 \%$ \\
\hline $\begin{array}{l}\text { Total } \\
\text { Kuesioner } \\
\text { yang tidak } \\
\text { kembali }\end{array}$ & 23 & $4,12 \%$ \\
\hline $\begin{array}{l}\text { Total } \\
\text { Kuesioner } \\
\text { yang tidak } \\
\text { dapat diolah }\end{array}$ & 18 & $10,00 \%$ \\
\hline $\begin{array}{l}\text { Total } \\
\text { Kuesioner } \\
\text { yang diolah } \\
\text { sebagai } \\
\text { sampel } \\
\text { penelitian }\end{array}$ & 109 & $85,33 \%$ \\
\hline
\end{tabular}

Sumber: data primer yang diolah peneliti (2019) 
Tabel 2

Profil Responden

\begin{tabular}{|c|c|c|}
\hline & Jumlah Responden & Perse \\
\hline \multicolumn{3}{|l|}{ Jenis Kelamin: } \\
\hline Laki-laki & 36 & \\
\hline Perempuan. & 73 & \\
\hline Total & 109 & \\
\hline \multicolumn{3}{|l|}{ Pendidikan: } \\
\hline SMU/SMK & 2 & \\
\hline S1 & 90 & \\
\hline \$2 & 17 & \\
\hline Total & 109 & \\
\hline \multicolumn{3}{|l|}{ Pengalaman Kerja: } \\
\hline $18 / d 3$ tahun & 9 & \\
\hline $33 \mathrm{~s} / \mathrm{d} 5$ thlum & 25 & \\
\hline$>5$ tahun & 75 & \\
\hline Total & 109 & \\
\hline \multicolumn{3}{|l|}{ Jabatan: } \\
\hline Ka Bag Administrasi & 28 & \\
\hline $\mathrm{KaBag}$ Keungmg & 30 & \\
\hline Ka Bag Customer Service & 36 & \\
\hline Ka Bag Kredit & 15 & \\
\hline Total & 109 & \\
\hline
\end{tabular}

Sumber: data olah penelitian (2019)

\section{Uji Asumsi Klasik}

\section{Uji Normalitas}

Cara pengujian yang digunakan dalam penelitian ini adalah dengan menggunakan uji Kolmogorov-Smirnov Test (Priyatno, 2016). Dari input data dan perhitungan yang dilakukan secara komputerisasi melalui program SPSS 24.0 diperoleh hasil sebagai berikut:

Tabel 3

Hasil Uji Normalitas

(Kolmogorov-Smirnov)

\begin{tabular}{|c|c|c|}
\hline \multicolumn{3}{|c|}{ One-Sample Kolmogorov-Smirnov Test } \\
\hline & & $\begin{array}{l}\text { Unstandardized } \\
\text { Residual }\end{array}$ \\
\hline \multicolumn{2}{|l|}{$\mathrm{N}$} & 109 \\
\hline \multirow[t]{2}{*}{ Normal Parameters ${ }^{\mathrm{a}, \mathrm{b}}$} & Mean & .36911790 \\
\hline & Std. Deviation & .47319214 \\
\hline \multirow[t]{3}{*}{ Most Extreme Differences } & Absolute & .138 \\
\hline & Positive & .097 \\
\hline & Negative & -.138 \\
\hline \multicolumn{2}{|l|}{ Test Statistic } & .138 \\
\hline \multicolumn{2}{|l|}{ Asymp. Sig. (2-tailed) } & $0.881^{\mathrm{a}}$ \\
\hline \multicolumn{3}{|l|}{ a. Test distribution is Nomal. } \\
\hline
\end{tabular}

Sumber: Data primer olahan SPSS (2019)
Dari tabel di atas dapat diketahui bahwa nilai signifikansi (sig) pada KolmogorovSmirnov sebesar 0,881; karena signifikansi lebih dari 0,05 maka residual terdistribusi dengan normal.

\section{Uji Multikolinearitas}

Hasil uji multikolinearitas dapat dilihat pada tabel berikut:

\section{Tabel 4}

Hasil Uji Multikolinearitas

\begin{tabular}{|c|c|c|c|c|c|c|c|}
\hline \multicolumn{8}{|c|}{ Coefficients $^{2}$} \\
\hline \multirow[b]{2}{*}{ Model } & \multicolumn{2}{|c|}{$\begin{array}{l}\text { Unstandardized } \\
\text { Coefficients }\end{array}$} & \multirow{2}{*}{$\begin{array}{c}\text { Standardized } \\
\text { Coefficients } \\
\text { Beta }\end{array}$} & \multirow[b]{2}{*}{ t } & \multirow[b]{2}{*}{ Sig. } & \multicolumn{2}{|c|}{$\begin{array}{c}\text { Collineanity } \\
\text { Statistics }\end{array}$} \\
\hline & $B$ & Std. Emor & & & & \begin{tabular}{|l|} 
Tolerance \\
\end{tabular} & VIF \\
\hline $1 \quad$ (Constant) & 3.599 & .612 & & 5.885 & .000 & & \\
\hline Sis_Dis & .450 & .078 & .491 & 5.750 & .000 & .965 & 1.036 \\
\hline Ket__ing & .125 & .075 & .140 & .1 .663 & .099 & 995 & 1.005 \\
\hline Asm_Inf & .110 & .103 & .091 & -1.071 & .287 & .968 & 1.033 \\
\hline
\end{tabular}

\section{Sumber: Data primer olahan SPSS} (2019)

Hasil pengolahan data menunjukkan variabel independen memiliki nilai Tolerance sebesar 0,$965 ; 0,995 ; 0,968$ yang artinya semua variabel independen lebih besar dari 0,10 yang berarti tidak ada korelasi antar variabel independen.

Hasil perhitungan nilai Variance Inflation Factor (VIF) juga menunjukkan hal yang sama dimana tidak ada satu pun variabel independen yang memiliki nilai VIF lebih dari 10, karena hasilnya adalah 1,$036 ; 1,005 ;$ dan 1,033. Jadi dapat disimpulkan di dalam penelitian ini tidak ada multikolinearitas antar variabel independen dalam model regresi. 


\section{Uji Heteroskedastisitas}

Pengujian ada tidaknya heteroskedastisitas pada penelitian ini menggunakan uji Glejser.

Tabel.5

Uji Heteroskedastisitas

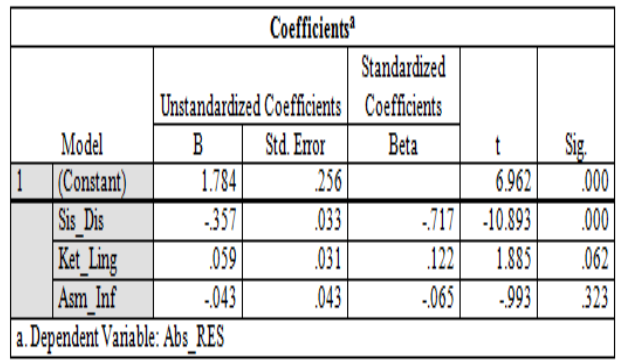

Dari tabel di atas dapat diketahui bahwa nilai signifikan uji t variabel independen yang ada pada penelitian ini dengan Absolute Residual (ABS_RES) lebih dari 0,05 untuk variabel Ketidakpastian Lingkungan dan Asimetri Informasi, sedangkan untuk variabel sistem desentralisasi tidak lebih dari 0,05 yang dapat disimpulkan bahwa pada model regresi terdapat ada masalah heteroskedastisitas, karena variabel sistem desentralisasi senilai 0,000 yang berarti kurang dari 0,05.

\section{Uji Autokorelasi}

Berikut tabel hasil uji Durbin Watson:

Tabel 6

Hasil Uji Autokorelasi

\begin{tabular}{|c|c|c|c|c|c|}
\hline \multicolumn{6}{|c|}{ Model Summary ${ }^{b}$} \\
\hline Model & $R$ & RS Square & $\begin{array}{l}\text { Adjusted R } \\
\text { Square }\end{array}$ & $\begin{array}{l}\text { Std. Error of the } \\
\text { Estimate }\end{array}$ & Durbin. \\
\hline 1 & $5111^{\mathrm{2}}$ & .261 & 24 & .480 & \\
\hline \multicolumn{6}{|c|}{ a.Predictors: (Constant), Asm Inf, Ket Limg, Sis Dis } \\
\hline b.Deper & Iariable: : & in Man & & & \\
\hline
\end{tabular}

\section{Sumber: Data primer olahan SPSS (2019)}

Berdasarkan tabel di atas, dapat terlihat nilai Durbin Watson (DW) sebesar 2.315. Dengan tingkat signifikansi $5 \%$ dan banyaknya $\mathrm{n}$ adalah 109 serta adanya 4 variabel maka nilai $\mathrm{dU}=1,74459$ dan $\mathrm{dL}=$ 1,63165. Maka dapat disimpulkan :

- tidak terdapat autokorelasi positif karena d > dU ; 2,315 > 1,74459

- tidak dapat disimpulkan apakah terdapat autokorelasi negatif karena $\mathrm{dL}<4-\mathrm{d}<\mathrm{dU} ; 1,63165$ $<1,685<1,74459$

\section{Uji Korelasi dan Koefisien Determinasi}

Hasil uji korelasi dan koefisien determinasi dapat dilihat pada tabel 7 di bawah ini.

\section{Tabel 7}

\section{Hasil Uji Korelasi dan Koefisien Determinasi}

\begin{tabular}{|l|c|r|r|r|}
\hline \multicolumn{5}{|c|}{ Model Summary } \\
\hline Model & \multicolumn{1}{|c|}{$\mathrm{R}$} & R Square & $\begin{array}{c}\text { Adjusted R } \\
\text { Square }\end{array}$ & $\begin{array}{c}\text { Std. Error of the } \\
\text { Estimate }\end{array}$ \\
\hline 1 & $.511^{\mathrm{a}}$ & .261 & .240 & .480 \\
\hline a. Predictors: (Constant),Asm_Inf,Ket__Ling, Sis_Dis & \\
\hline \multicolumn{2}{|l}{ b. Dependent Variable: Kin_Man } \\
\hline
\end{tabular}

\section{Sumber: Data primer olahan SPSS} (2019)

Hasil uji korelasi pada tabel 7 menunjukkan nilai $\mathrm{R}$ yang diperoleh bernilai positif yaitu sebesar 0,511 . Nilai $R$ yang diperoleh dalam penelitian ini lebih besar dari 0,5 yang menunjukkan bahwa terdapat hubungan yang kuat dan positif antara sistem desentralisasi, ketidakpastian lingkungan, dan asimetri informasi, dengan kinerja manajerial. Nilai adjusted $R$-square yang diperoleh dalam penelitian ini yaitu sebesar 0,240. Ini berarti $24 \%$ besarnya variasi kinerja manajerial pada penelitian ini dapat dijelaskan oleh sistem desentralisasi, ketidakpastian lingkungan, dan asimetri informasi.Dan sebesar $76 \%$ variasi kinerja manajerial perusahaan dijelaskan oleh faktor-faktor lain yang tidak termasuk dalam model regresi pada penelitian ini.

Dengan demikian, dapat disimpulkan variabel sistem desentralisasi, ketidakpastian lingkungan dan asimetri 
informasi belum mampu memberikan semua informasi yang diperlukan untuk memprediksi variasi kinerja manajerial di dalam perusahaan yang diteliti pada penelitian ini.

\section{Uji F}

Hasil uji F dapat dilihat pada tabel 8

\section{Tabel 8}

Hasil Uji F

\begin{tabular}{|c|c|c|c|c|c|}
\hline & \multicolumn{5}{|c|}{$\mathrm{ANOVA}^{\mathrm{a}}$} \\
\hline & Model & Sum of Squares & $\mathrm{Df}$ & Mean Square & $\mathrm{F}$ \\
\hline \multirow[t]{3}{*}{1} & Regession & 8.536 & 3 & 2.845 & 12.35 \\
\hline & Residual & 24.182 & 105 & .230 & \\
\hline & \begin{tabular}{|l|} 
Total \\
\end{tabular} & 32.718 & 108 & & \\
\hline & ndent Vaniabl & in Man & & & \\
\hline
\end{tabular}

\section{Sumber: Data primer olahan SPSS} (2018)

Pada tabel 8 menunjukkan nilai $\mathrm{F}$ sebesar 12,354 dan nilai sig. (2-tailed) yang diperoleh sebesar 0,000 yang berarti nilai sig.(2-tailed) tersebut di bawah 0,05. Ini berarti Ha tidak dapat ditolak, jadi model regresi layak dan tepat digunakan dalam penelitian.

\section{Uji T}

Hasil uji t dapat dilihat pada tabel 9

Tabel 9

Hasil Uji T

\begin{tabular}{|c|c|c|c|c|c|}
\hline \multicolumn{6}{|c|}{ Coefficients $^{2}$} \\
\hline \multirow{2}{*}{\multicolumn{2}{|c|}{ Model }} & \multicolumn{2}{|c|}{ Unstandardized Coefficients } & $\begin{array}{c}\text { Standardized } \\
\text { Coefficients }\end{array}$ & \\
\hline & & $\mathrm{B}$ & Std. Enror & Beta & $\mathrm{t}$ \\
\hline \multirow[t]{5}{*}{1} & (Constant) & 3.599 & .612 & & 5.8 \\
\hline & Sis_Dis & .450 & .078 & .491 & 5.7 \\
\hline & Ket_Ling & .125 & .075 & .140 & 1.6 \\
\hline & SisDis_AsmInf & .287 & .143 & 1.765 & 2.0 \\
\hline & $\begin{array}{l}\text { KetLing_AsmI } \\
\text { nf }\end{array}$ & .161 & .248 & 973 & .6 \\
\hline & endent Variable & Sin_Man & & & \\
\hline
\end{tabular}

\section{Sumber: Data primer olahan SPSS} (2019)

Berdasarkan tabel 9 diatas, maka model regresi dapat dirumuskan sebagai berikut:
Kin_Man $=3,599+0,450$ Sis_Dis $+0,125$

Ket_Ling + 0,287 Sis Dis_AsmInf +0,161

KetLing_AsmInf + e

Persamaan regresi diatas dapat diinterpretasikan sebagai berikut.

1. Nilai konstanta yang diperoleh sebesar 3,599 artinya apabila sistem desentralisasi, ketidakpastian lingkungan, dan asimetri informasi bernilai nol, maka kinerja manajerial bernilai 3,599 satuan.

2. Koefisien regresi nilai sistem desentralisasi sebesar 0,450 berarti bahwa jika sistem desentralisasi naik 1 satuan, maka akan meningkatkan nilai kinerja manajerial sebesar 0,450 satuan dengan asumsi ketidakpastian lingkungan dan asimetri informasi adalah konstan.

3. Koefisien regresi ketidakpastian lingkungan sebesar 0,125 berarti apabila ketidakpastian lingkungan naik 1 satuan, maka akan meningkatkan nilai kinerja manajerial sebesar 0,125 satuan dengan asumsi sistem desentralisasi dan asimetri informasi konstan.

\section{Interpretasi Data}

\section{Pengaruh Sistem Desentralisasi terhadap Kinerja Manajerial}

Berdasarkan hasil analisis data penelitian yang telah diuraikan di atas, hipotesis pada penelitian ini menunjukkan hasil bahwa sistem desentralisasi berpengaruh signifikan terhadap kinerja manajerial.Hasil pengujian hipotesis ini sejalan dengan penelitian Yazid (2012), Ingkiriwang (2013), dan Senduk (2017). Hal ini mengindikasikan bahwa semakin baik sistem desentralisasi, maka akan meningkatkan kinerja manajerial perusahaan. Pendelegasian merupakan pemberian tanggung jawab kepada kepala bagian dari beberapa level operasional dan otoritas di dalam membuat keputusan departemen yang menjadi tanggung jawabnya. 
Sistem desentralisasi sangat membantu manajemen tingkat tinggi (high level management) untuk fokus kepada masalah - masalah yang berkaitan dengan strategi perusahaan.Karena segala sesuatu yang berhubungan dengan kegiatan operasional perusahaan sudah dapat didelegasikan kepada tingkat manajemen yang lebih rendah (Low Level Management). Sinergi antara tingkat manajemen yang tinggi dengan yang lebih rendah ini akan mendorong peningkatan kinerja manajerial perusahaan.

\section{Pengaruh Ketidakpastian Lingkungan terhadap Kinerja Manajerial.}

Berdasarkan hasil analisis data penelitian yang telah diuraikan di atas, hipotesis pada penelitian ini menunjukkan hasil bahwa ketidakpastian lingkungan berpengaruh signifikan terhadap kinerja manajerial.Hasil pengujian hipotesis ini sejalan dengan penelitian Fiolita (2015), Frestilia (2013), dan Rahayu (2013).Hal ini mengindikasikan bahwa ketidakpastian lingkungan yang sangat erat dengan masalah informasi mendorong manajemen perusahaan untuk piawai dalam mengkaji dan mengelola informasi agar informasi tersebut berdaya guna untuk mengambil keputusan yang tepat sehingga tercipta kinerja manajerial yang unggul.

Ketidakpastian lingkungan yang tinggi dapat menyulitkan manajer dalam proses perencanaan, pengawasan dan pengambilan keputusan suatu organisasi. Perencanaan dan pengawasan akan menjadi problematik yang harus dihadapi oleh perusahaan di dalam situasi operasi yang tidak pasti yang disebabkan oleh kejadiankejadian di masa datang yang tidak dapat diprediksikan.

Asimetri Informasi memperkuat
pengaruh Sistem Desentralisasi terhadap
Kinerja Manajerial
Hasil penelitian ini menunjukkan bahwa
semakin tinggi asimetri informasi semakin
memperkuat pengaruh antara sistem

desentralisasi terhadap kinerja manajerial. Hal ini dapat dijelaskan sebagai berikut, adanya asimetri informasi antara high level management dan low level management akan memperkuat pengaruh sistem desentralisasi terhadap kinerja manajerial. Jadi mengindikasikan bahwa jika manajemen perusahaan semakin baik mengantisipasi asimetri informasi maka sistem desentralisasi akan semakin bermanfaat untuk meningkatkan kinerja manajerial perusahaan

\section{Asimetri Informasi Memperlemah Pengaruh Ketidakpastian Lingkungan terhadap Kinerja Manajerial.}

Hasil penelitian ini menunjukkan bahwa asimetri informasi memperlemah pengaruh antara ketidakpastian lingkungan terhadap kinerja manajerial.Variabel asimetri informasi pada penelitian ini sebagai variabel moderasi memperlemah pengaruh antara ketidakpastian lingkungan terhadap kinerja lingkungan. Hal ini menunjukkan peran asimetri informasi dalam sebuah perusahaan tidaklah diperlukan, karena memperlemah pengaruh ketidakpastian lingkungan terhadap kinerja manajerial

\section{Simpulan dan Saran}

\section{Simpulan}

Berdasarkan hasil penelitian yang telah dilakukan terdapat beberapa kesimpulan yang dapat dikemukakan oleh peneliti sebagai berikut:

1. Sistem desentralisasi berpengaruh secara signifikan terhadap kinerja manajerial perusahaan. Hal ini dikarenakan sistem desentralisasi dalam perusahaan bertujuan mendelegasikan otorisasi dengan memberikan tanggung jawab dan otoritas kepada kepala bagian dari beberapa level operasional dalam hal membuat keputusan yang berkaitan dengan bagian atau departemen yang menjadi tanggung jawabnya. Hal ini 
dapat meningkatkan kinerja manajerial perusahaan karena para kepala bagian termotivasi untuk mencapai target yang dibuat oleh mereka sendiri.

2. Ketidakpastian lingkungan berpengaruh secara signifikan terhadap kinerja manajerial perusahaan. Semakin baik laporan yang dihasilkan dari informasi sistem akuntansi manajemen akan dapat lebih membantu mengurangi ketidakpastian lingkungan dan memperbaiki kualitas keputusan yang dibuat oleh manajemen perusahaan. Hal ini dapat disimpulkan bahwa pada kondisi ketidakpastian lingkungan yang tinggi maka manajemen dituntut untuk dapat mengelola informasi yang ada agar dapat dipastikan bahwa informasi tersebut merupakan masukan yang dapat diandalkan dalam proses perencanaan, pengendalian, dan pengambilan keputusan suatu perusahaan.

3. Asimetri Informasi memperkuat pengaruh Sistem Desentralisasi terhadap Kinerja Manajerial. Asimetri Informasi yang ada harus dapat dikaji dan dikelola dengan benar agar membuat sistem desentralisasi mempunyai peran lebih di dalam kinerja manajerial, sehingga perusahaan akan dapat meningkatkan profitabilitas perusahaannya.

4. Asimetri Informasi yang ada tidak mempunyai peran dalam hal pengaruh ketidakpastian lingkungan terhadap pengaruh kinerja manajerial suatu perusahaan. Maka ada tidaknya asimetri informasi tidak mempunyai pengaruh terhadap kinerja manajerial perusahaan.

\section{Saran}

Berdasarkan pembahasan dan kesimpulan yang didapat pada penelitian ini, maka peneliti memberikan saran yang diharapkan untuk penelitian berikutnya, yaitu:
1 Sebaiknya pada penelitian selanjutnya sampel penelitian sebagai responden bukan hanya industri perbankan swasta yang terdaftar di Bursa Efek Indonesia, namun industri perbankan BUMN yang terdaftar di Bursa Efek Indonesia.

2 Beberapa faktor yang memengaruhi kinerja manajerial di dalam penelitian ini hanya terdiri dari tiga variabel yaitu sistem desentralisasi, ketidakpastian lingkungan, dan asimetri informasi. Sedangkan selain ketiga faktor tersebut masih banyak faktor lain yang memengaruhi kinerja manajerial, seperti sistem akuntansi manajemen dan good corporate governance yang dapat digunakan untuk penelitian berikutnya.

\section{Daftar Pustaka}

Fiolita, N. (2015) Pengaruh Intensitas Kompetisi dan Ketidakpastian Lingkungan Terhadap Kinerja Organisasi dengan Karakteristik Informasi Sistem Akuntansi Manajemen Sebagai Variabel Intervening (Studi Empiris Pada Perusahaan Asuransi di Kota Pekanbaru)..Jom FEKON, Vol. 2 No. 2.

Fitriani.(2013). Pengaruh Penggunaan Karakteristik Informasi Akuntansi Manajemen Terhadap Kinerja Manajerial.Jurnal Akuntansi. Vol. 1, No. 3.

Frestilia, N. (2013). Pengaruh pemanfaatan Teknologi Informasi, Karakteristik Informasi Sistem Akuntansi Manajemen dan Ketidakpastian Lingkungan Terhadap Kinerja Manajerial Studi Empiris Pada Perusahaan Perbankan di Kota 
Padang. JurnalAkuntansi. Vol. 1, No.1.

Hansen, D. R. dan Mowen, M. (2016). Cornerstones of Cost Management. Canada: Cengage Learning.

Herdiansyah, S. dan Prastiwi, A. (2012).Pengaruh Karakteristik Informasi Sistem Akuntansi Manajemen dan Desentralisasi Terhadap Kinerja Manajerial dengan Ketidakpastian Lingkungan Sebagai Variabel Moderating.Jurnal Akuntansi dan Bisnis Volt. 4 No. 2

Hofstede dan Kinerd, 1970, "A Strategy for Behavioral Research," The Accounting Review, Januari, hal.3854.

Ingkiriwang, O.F. (2013). Pengaruh Desentralisasi dan Sistem Akuntansi Manajemen Terhadap Kinerja Manajer Dealer di Manado.Jurnal EMBA Vol.1 No.3 Juni 2013, Hal.818-825.

Ishak The., dan Sugiono. 2015. Akuntansi, Informasi Dalam Pengambilan Keputusan.Jakarta: PT. Grasindo

James A.F. Stoner and R. Edward Freeman, (2015).Manajemen Jilid I, Edisi Kelima, Penerjemah Wlhelmus, W.Bakowatum dan Benyamin Molan, Penerbit Intermedia, Jakarta.

Lathifah, I. (2012). Peran Karakteristik Sistem Akuntansi Manajemen Sebagai Mediator Hubungan Antara Ketidakpastian Lingkungan Dengan Kinerja Manajerial.Jurnal Reviu Akuntansi dan Keuangan, Vol.2 No. 2,pp 313-322.

Mabrurah, L., Islahuddin, dan Arfan, M. (2017). Pengaruh ukuran perusahaan, asimetri informasi, komposisi dewan komisaris, dan ukuran dewan komisaris terhadap manajemen laba perusahaan manufaktur yang terdaftar di Bursa Efek Indonesia. Jurnal Megister Akuntansi Pascasarjana Universitas Syiah Kuala. Vol 6, No.2, pp. 12-19.
Mulyadi.

Manajemen.STIE

(2015)..Akuntansi

Yogyakarta.

Putri, D.L, Wardi, J., Farwitawati, R. (2014). Pengaruh Ketidakpastian Lingkungan terhadap Karakteristik Sistem Informasi Akuntansi Manajemen Pada Bank Syariah mandiri Pekanbaru. Pekbis Jurnal, Vol.8, No.2, Juli 2016: 144-154.

Rahayu, M. (2013).Pengaruh Intensitas Informasi Akuntansi Manajemen TerhadapKinerja Manajerial Dengan Ketidakpastian Lingkungan Sebagai Variabel Intervening(Studi Empiris Perusahaan Manufaktur di Kota Padang).Jurnal Akuntansi. Vol. 1, No.1.

Salman, K. dan Farid, M. (2016). Akuntansi Manajemen Alat Pengukuran dan Pengambilan Keputusan Manajerial. Jakarta: Indeks.

Senduk, J.M., Ilat, V, dan Tirayoh, V. (2017). Pengaruh Desentralisasi, Strategi Bisnis dan Pemanfaatan Informasi Sistem Akuntansi Manajemen Terhadap Kinerja Manajerial pada PT. Bank Mandiri di Manado. Jurnal Riset Akuntansi Going Concern, Vol. 12, No.1, pp. 73-82.

Setiawan, A. S. (2012). Ketidakpastian Lingkungan Memoderasi Hubungan Antara Sistem Akuntansi Manajemen Terhadap Kinerja Manajerial (Studi Empiris Pada Perusahaan Perbankan di Kota Palembang). Jurnal Akuntansi, Vol. XVI No. 01, hal 99-111.

Sisaye, S. dan Birnberg, J. (2010).Extent and scope of diffusion and adoption of process innovations in management accounting systems.International Journal of Accounting and Information Management. Vol. 18 No. 2, pp. 118-139.

Sodikin, Slamet. 2015. Akuntansi Manajemen Sebuah Pengantar, 
Edisi Kelima. Yogyakarta: Unit Penerbit dan Percetakan Sekolah Tinggi Ilmu Manajemen YKPN.

Sigilipu, S. (2013). Pengaruh Penerapan Informasi Akuntansi Manajemen Dan Sistem Pengukuran Kinerja Terhadap Kinerja Manajerial Pada PT. PLN (persero) Wilayah Suluttenggo. Jurnal EMBA, Vol.1 No.3 Juni 2013, Hal.239-247. ISSN 2303-1174.

Wirjono, E. R. (2013). Hubungan Antara Sistem Akuntansi Manajemen dan Ketidakpastian Lingkungan yang Dirasakan Terhadap Kinerja Manajerial.Jurnal Ilmiah Akuntansi dan Bisnis, Vol. 8, No. 1.

Yazid, H. (2012). Pengaruh Ketidakpastian Tugas dan Desentralisasi Terhadap Kinerja Manajerial Dengan Sistem Akuntansi Manajemen Sebagai Variabel Intervening (Studi Pada PT.Gunanusa Utama Fabricators).JurnalAkuntansi, Vol. 1, No. 1, PP 53- 56.

Yuliansyah, Y., Bui, B., \& Mohamed, N. 2016. How Managers Use PMS to Induce Behavioural Change in Enhancing Governance.

Yuliansyah, Y., \& Khan, A. A. 2017.A revisit of the participative budgeting and employees' self-efficacy interrelationship $\quad-\quad$ empirical evidence from Indonesia's public sector.International Review of Public Administration, 22(3): 213230.

Yuliansyah, Y., \& Razimi, M. 2015. Nonfinancial performance measures and managerial performance: the mediation role of innovation in an Indonesian stock exchange-listed organization. Problems and Perspectives inManagement, 13(4): 135-145.

http://www.asean.org 